\title{
Análise funcional dos estabilizadores patelares
}

\author{
Functional analysis of the patellar stabilizers
}

Débora Bevilaqua Grosslin, Vanessa Monteiro Pedro ${ }^{2}$, Fausto Bérzin ${ }^{3}$

\section{RESUMO}

O músculo vasto medial obliquo (VMO) desempenha importante papel na estabilização medial da patela. No entanto, o padrão de recrutamento dos componentes laterais, o músculo vasto lateral longo (VLL) e vasto lateral obliquo (VLO) não está estabelecido. O objetivo deste trabalho foi analisar a atividade eletromiográfica dos músculos VMO, VLL e VLO de 21 indivíduos saudáveis ( $X=23,3$ e DP=2,9), sendo 10 mulheres e 11 homens, sem história clínica de dor ou lesão osteomioarticular. Para tanto foi utilizado um eletromiógrafo NICOLET VIKING II de 8 canais (NICOLET Biomedical Instruments) e eletrodos bipolares de superfície para registrar a atividade elétrica dos músculos VMO, VLL e VLO durante a realização de exercícios isométricos de extensão do joelho a $15^{\circ}$ e $90^{\circ}$ de flexão. Os dados eletromiográficos foram normalizados pela contração isométrica voluntária máxima de extensão do joelho a $50^{\circ}$ de flexão e revelaram que os músculos VLL e VLO apresentam diferença significativa no padrão de recrutamento podendo ser considerados fisiologicamente distintos. O músculo VMO desempenhou juntamente com o VLO um papel recíproco e sincrônico na estabilização patelar e apresentou maior ativação em relação ao músculo VLL nos exercícios isométricos de extensão do joelho a $90^{\circ}$.

Descritores: Joelho; Músculo; Eletromiografia.

\section{INTRODUÇÃO}

As desordens femoropatelares são provavelmente a causa mais comum de patologia no joelho encontradas em clínicas de ortopedia e medicina esportiva(6). Os pacientes com sintomas de dor femoropatelar permanece como um dos maiores desafios clínicos em medicina de reabilitação a despeito dos recentes avanços no entendimento e tratamento de diversas condições do joelho(25).

\section{SUMMARY}

The vastus medialis obliquus muscle (VMO) performs an important role in the medial patellar stability. However, the recruitment of the lateral components, the vastus lateralis longus (VLL) and vastus laterallis oblique (VLO) is not established. The main purpose of this work was to investigate the electromyographic (EMG) activity of the VMO, VLL and VLO muscles of twenty one health volunteers $(X=23,3 \pm D P 2,9), 10$ female and eleven males, without clinical pain symptoms or osteomioarticular injuries EMG NICOLET VIKING II was used with eight channels (NICOLET Biomedical Instruments, and bipolar electrodes surface in order to record the electrical activity of VMO, VLL and VLO muscles during a isometric knee extension at $15^{\circ}$ and $90^{\circ}$. The EMG data were normalized by maximum voluntary contraction (MIVC) of the knee flexion at $50^{\circ}$ has shown that the VLL and VLO muscles demonstrated significant difference in recruitment pattern and they can be considered physiologically distinct. The VMO and VLO muscles performed synchronic and reciprocal role in the patellar stability and the VMO muscle performed higher activity compared with the VLL muscle in isometric knee extension at $90^{\circ}$

Key words: Knee, Muscle, Electromyography.

\section{INTRODUCTION}

The patellofemoral disorders are the most likely pathology in the knee seen in orthopedics and sports medicine clinics ${ }^{(6)}$. The patients with patellofemoral pain symptoms are one of the biggest clinical challenges in rehabilitation medicine considering the most recent advances in the diagnoses and treatment of several knees condition ${ }^{(25)}$.
Trabalho realizado no Laboratório de Eletromiografia do Departamento de Morfologia da Faculdade de Odontologia de Piracicaba (FOP)UNICAMP

1.Profa. Doutora do Departamento de Biomecânica, Medicina e Reabilitação do Aparelho Locomotor-FMRP - USP

2.Profa. Adjunto-IV do Departamento de Fisioterapia - UFSCar

3. Prof. Titular do Departamento de Morfologia (FOP - UNICAMP)

Endereço para Correspondência

Av. Bandeirantes, 3900 - Cep: 14049-900 Ribeirão Preto - SP - Tel: (16)

6022418 Fax: (16) 6330336 - e-mail: deborabg@fmrp.usp.br
Work performed at the Electromyography Laboratory of Morphology Department of Dentistry College of Piracicaba (FOP) - UNICAMP

1 - PhD Professor of the Biomechanical Department, Medicine and Rehabilitation of the Locomotors- FMRP - USP

2 - Associate Professor - IV Professor of the Physiotherapy Department UFSCar

3 - Chairman of the morphology Department (FOP - UNICAMP)

Adress: Av. Bandeirantes, 3900 - Cep: 14049-900 Ribeirão Preto - SP . Phone (16) 6022418 Fax: (16) 6330336 -e-mail: deborabg@fmrp.usp.br 
Uma das características mais comuns nos pacientes com dor femoropatelar é o desalinhamento do mecanismo extensor, que resulta em atrofia e diminuição da força do músculo vasto medial e desequilíbrio entre os componentes laterais e mediais do quadríceps ${ }^{(4,22)}$.

O vasto medial é dividido em duas porções, uma proximal denominada de vasto medial longo (VML) e outra distal, o vasto medial obliquo (VMO). Essas porções apresentam diferenças anatômicas $^{(2,11,12,23)}$, funcionais ${ }^{(2,13,17)}$, histoquímicas ${ }^{(21)}$ e também no padrão de inervação ${ }^{(12,18,20)}$. Mais recentemente, o músculo vasto lateral passou a ser estudado anatomicamente e, como o VMO, também foi dividido em duas porções: uma proximal, denominada de vasto lateral longo (VLL) e outra distal, o vasto lateral oblíquo (VLO) ${ }^{(1,11,18,23)}$ (Figura1). Além disso, o VLO passou a ser estudado também pela importância clínica na técnica cirúrgica do release lateral, cuja liberação diminui o tempo de recuperação pós operatória, quando comparado com a transecção de todo vasto lateral ${ }^{(7)}$.

A atividade eletromiográfica dos músculos VMO e VLL tem sido bastante estudada em cadeia cinética aberta e em diferentes ângulos de flexão do joelho ${ }^{(3,4,6,15)}$. No entanto, apesar de Weinstabl et al. ${ }^{(23)}$ sugerirem diferenças funcionais entre os músculos VLL e VLO, o padrão de atividade elétrica destes músculos ainda não foi estudado. Morrish e Woledge ${ }^{(16)}$ compararam o padrão de atividade elétrica dos músculos VMO e VLO em indivíduos normais em exercícios de cadeia cinética aberta a $20^{\circ}$ de flexão do joelho e não encontraram diferença significativa entre os dois músculos neste ângulo.

Considerando a importância de melhor entendimento dos fatores envolvidos na disfunção femoropatelar e do pouco conhecimento do papel dos componentes mediais e laterais do quadríceps na estabilização da patela, o objetivo deste estudo foi analisar a atividade elétrica dos músculos VMO, VLL e VLO em exercícios de extensão do joeIho em cadeia cinética aberta nos ângulos de $15^{\circ} \mathrm{e}$ $90^{\circ}$ de flexão.

\section{MATERIAL E MÉTODOS SUJEITOS}

Os músculos vasto medial oblíquo (VMO), vasto lateral oblíquo (VLO) e vasto lateral longo (VLL) foram analisados eletromiograficamente em 21 voluntários, sendo 10 do sexo feminino e 11 do sexo masculino, com idade de 19 a 28 anos ( $X=23,3 \pm 2,9)$ sem história clínica de cirurgias, dor ou lesão osteomioarticular nos membros inferiores. O estudo foi conduzido de acordo com a resolução 196/96 do Conselho Nacional de Saúde.

\section{EQUIPAMENTOS}

Os registros eletromiográficos foram captados por eletrodos bipolares de superfície com diâmetro de $11 \mathrm{~mm}$ e superfície de detecção de $2 \mathrm{~mm}$ conectados ao eletromiógrafo VIKING II de oito canais (NICOLET BIOMEDICAL INSTRUMENTS). A calibração do equipamento variou de 200 a $500 \mathrm{mV}$ divisão e a velocidade de deslocamento do feixe foi de $200 \mathrm{~ms} /$ divisão. Os filtros foram fixados numa amplitude de $10 \mathrm{~Hz}$ para baixa freqüência e de $10 \mathrm{KHz}$ para alta freqüência

\section{PROCEDIMENTOS}

Os eletrodos foram fixados sobre a pele, previa-
One of the most common characteristics in patients with patellofemoral pain is the extensor mechanism disorder, which results in atrophy and strength reduction of vastus medialis muscle and unbalancing of the lateralis and medialis quadriceps components ${ }^{(4,22)}$.

The vastus mediallis is divided into two parts, one proximal called vastus mediallis longus (VML) and another distal one, the vastus mediallis obliquus (VMO). These parts show anatomical $^{(2,11,12,23)}$, functional ${ }^{(2,13,17)}$, histochemistry ${ }^{(21)}$ differences and in the pattern of innervations as we/l(12,18,20) (Figure 1). In addition, the VLO started also be studied because of clinical surgical importance technique of release lateral, which the releasing decreases the post operation recovery, as compared with the transaction of all vastus lateralis ${ }^{(7)}$.

The muscles VMO and VLL electromyographic activity have been studied in each opening kinetic chain and in different angles of knee flexion ${ }^{(3,4,6,15)}$. However, despite Weinstabl et al (23) suggest functional differences between the VLL and VLO muscles, the electrical pattern activity has not been studied yet. Morrish \& Woledge ${ }^{(16)}$ compared the electrical pattern activity of the VMO and VLO muscles in normal clinical patients doing exercise of kinetic chain at $20^{\circ}$ knee flexion and the authors not found any significant difference between these two muscles with this angle.

Considering the importance of understanding the involved factors in patellofemoral this disorder and the poor knowledge about the role of the medially and laterallis components of the quadriceps in the patella stability, the main purpose of this study was figure out the electrical VMO, VLL, and VLO muscles activities with the flexion knee extension exercise in a kinetic at $15^{\circ}$ and $90^{\circ}$ of the knee flexion.

\section{MATERIAL AN METHODS}

The vastus medialis obliquus (VMO), vastus lateralis obliquus (VLO) and vastus lateralis longus (VLL) were evaluated by the use of electromyography in 21 volunteers, ten female and 11 male, aged from 19 to $28(X=23,3 \pm 2.9)$ had no previous surgery, pain or osteomyarticular injury in the lower limbs. The study was led with the 196/96 resolution of the Health National Council.

\section{EQUIPAMENT}

Figura 1 - Vista lateral da coxa direita evidenciando o músculo vasto lateral oblíquo (VLO) com sua origem no septo intermuscular lateral (SIL) e sua inserção na borda superior e lateral da patela $(P)$, músculo vasto lateral longo (VLL).

Figure 1 - Lateral view of the right thigh evincing the oblique lateral vast muscle (VLO) with its origin in the lateral intermuscular septum (SIL) and its insertion in the upper and lateral patellar edge, long lateral vast muscle (VLL).
Electromyography records were obtained by bipolar surface electrodes with $11 \mathrm{~mm}$ diameter and detection surface of $2 \mathrm{~mm}$ connected to the electromyography Viking II of eight channels (Nicolet Biomedical Instruments). The calibration of the equipment ranged from 200 to $500 \mu \mathrm{V}$, the division and speed of the beam displacement was of $200 \mathrm{~ms} /$ division. The filters were fixed with amplitude of $10 \mathrm{~Hz}$ low frequency and $10 \mathrm{KHz}$ high frequency.

\section{PROCEDURES}

The electrodes were fixed on the skin, previously trichotomized and hygienized with alcohol at $70 \%$, in order to reduce the impedance and eliminate any unexpected interferences. Before the elec- 
mente tricotomizada e realizada a limpeza com álcool $70 \%$, a fim de reduzir a impedância e eliminar eventuais interferências. Antes da fixação os eletrodos foram untados com gel eletrocondutor e fixados à pele no sentido longitudinal das fibras musculares por meio de fita adesiva micropore (3M do Brasil). A distância entre o centro de cada eletrodo foi de 2 centímetros. Um eletrodo terra também untado com gel eletrocondutor foi fixado à tuberosidade anterior da tíbia.

Para a colocação dos eletrodos nas diferentes porções do músculo quadríceps, foi traçado uma linha da espinha ilíaca ântero-superior (EIAS) ao centro da patela $(C)$, para servir de referência na medida dos ângulos de inclinação de cada porção(1). O par de eletrodos sobre o $\mathrm{m}$. VMO foi posicionado sobre o ventre muscular numa inclinação de $55^{0(12)}$. Para o m. VLL os eletrodos foram posicionados a $15 \mathrm{~cm}$ da borda superolateral da patela numa inclinação de 13.6 . O VLO apresenta sua porção superficial localizada cerca de 2,2 cm do epicôndilo lateral, com um comprimento superficial de $8,95 \mathrm{~cm}$ em média, para a colocação dos eletrodos sobre este músculo localizou-se o epicôndilo lateral do fêmur e o início e o meio do ventre muscular do VLO com uma inclinação de 50,4 ${ }^{\text {(1) }}$ (Figura 2).

\section{POSIÇÕES E EXERCícIOS}

Os exercícios de extensão isométrica do joelho nos ângulos de $15^{\circ}, 50^{\circ}$ e $90^{\circ}$ de flexão do joelho, foram realizados em uma mesa flexo-extensora ${ }^{(14)}$, que permitia a fixação mecânica do membro nos diferentes ângulos de flexão do joelho, proporcionando uma contração isométrica voluntária máxima (CIVM) em cada ângulo. O voluntário permaneceu sentado com o tronco e o quadril fletidos a $90^{\circ}$ e estabilizado com dois cintos: um axilar e outro pélvico.

A ordem de execução dos exercícios foi aleatória e antes do início de cada exame foi realizado uma familiarização com os exercícios. O tempo de execução de cada contração foi de 5 segundos com intervalo de 60 segundos entre cada repetição e de 10 minutos entre cada série de exercícios. Os dados eletromiográficos foram normalizados pela CIVM de extensão do joelho a $50^{\circ}$ de flexão do joelho de acordo com Hanten e Schulthies ${ }^{(8)}$.

Para comparação entre os músculos nos diferentes ângulos foi empregado o teste de análise de variância não paramétrico (ANOVA).

\section{RESULTADOS}

A comparação entre os músculos VMO, VLL e VLO revelou que no exercício de extensão isométrica a $15^{\circ}$ de flexão do joelho não há diferença na ativação destes músculos $(p=0.06)$. Por outro lado, ao realizar os mesmos exercícios com o joelho fletido no ângulo de $90^{\circ}$ os músculos VMO e VLO apresentaram o mesmo comportamento e foram significativamente mais ativos do que o músculo VLL $(p=0.02)$ (Tabela 1).

Na comparação entre ângulos, apenas o músculo VLL apresentou padrão de ativação distinto, isto é, apresentou maior atividade nos exercícios de extensão a $15^{\circ}$ do que a $90^{\circ}(p=0.04)$. Por outro lado, a variação dos ângulos não interferiu na atividade dos músculos VMO e VLO (Tabela 1) trodes fixation they had been greased with gel and fixed to the skin at longitudinal direction from the muscular fibers with microspores scotch tape (3M of Brazil). The distance between the centers of each electrode was of $2 \mathrm{~cm}$. An earthed connected electrode was greased with gel and fixed to the anterior tibia tuberosity.

To install the electrodes in different parts of the quadriceps muscle, a line was traced from the antero superior iliac spine (ASIS) to the center of patella, as a pattern of the inclination angle of the measurement of each portion ${ }^{(1)}$. The pair of electrodes on the VMO was placed on the belly of the muscle at an inclination of $55^{\circ(12)}$. The VLL electrodes were placed at $15 \mathrm{~cm}$ from the superior and lateral edge of patella at an inclination of $13.6^{\circ}$. The VLO shows its superficial part located around 2,2 cm of the lateralis epicondyle, with a superficial length of about $8.9 \mathrm{~cm}$. To insert the electrodes on this muscle, the femoral lateralis epicondyle was located and the beginning and center of the VLO belly muscle at an inclination of $50,4^{\text {(1) }}$ (Figure 2).

\section{POSITIONS AND EXERCISES}

The knee isometric extension exercises at $15^{\circ}$, $50^{\circ}$ and $90^{\circ}$ angles of knee flexion were performed on an extensor flexor table, which allowed the limb mechanical fixation of different knee flexion angle, leading to a maximum voluntary isometric contraction (MVIC) in each exercise performance. The volunteer remained sat with the trunk and hips flexioned at $90^{\circ}$ and stabilized with two belts: an auxiliary and a pelvic one.

The exercise performance order was random and before the beginning of each test, the familiarization with the exercises was done. The time performance of each contraction was of 5 seconds with a break of 60 seconds between each repetition and ten minutes between the set of exercises. The electromyographic data were normalized considering the MVIC of the knee extension at $50^{\circ}$ of the knee flexion according to Hanten \& Schulthies ${ }^{(8)}$

Comparing the muscles at the different angles studied, analyses of variance test was used.

\section{RESULTS}

The comparison among VMO, VLL and VLO muscles showed that isometric extension exercise at $15^{\circ}$ knee flexion there is difference in activation pattern of these muscles $(p=0.06)$. On the other hand, the performance of the same exercises at $90^{\circ}$ of knee flexion, the VMO and VLO muscles showed the same behaviour and were significantly more active than the VLL muscle $(p=0,02)$ (Table 1).

The comparison among the angles, only the VLL muscle showed a distinct activation pattern, that is, higher activity at the extension exercise at $15^{\circ}$ than at $90^{\circ}(p=0,04)$. On the other hand the angle variation did not make any difference in the VMO and VLO muscles (Table 1) 


\begin{tabular}{|c|c|c|c|c|c|c|c|}
\hline & \multicolumn{2}{|c|}{ VMO } & \multicolumn{2}{|c|}{ VLL } & \multicolumn{2}{|c|}{ VLO } & \multirow[b]{2}{*}{ Valor de p para comparação entre músculos } \\
\hline & $\mathrm{X}$ & DP & $X$ & DP & $X$ & $\mathrm{DP}$ & \\
\hline & & & & & & & Value of $p$ comparison among muscles \\
\hline $15^{\circ}$ & 148,6 & 84,9 & 161,5 & 56,1 & 136,8 & 46,6 & 0.06 \\
\hline $90^{\circ}$ & 154,4 & 49,3 & 131,3 & 43,9 & 158,7 & 58,7 & 0.02 \\
\hline Valor de p para comparação entre os ângulos estudados & 0.82 & 0.004 & 0.27 & & & & \\
\hline P. value considered for comparisons among studied angles & & & & & & & \\
\hline & & & & & & & \\
\hline
\end{tabular}

Tabela 1 - Média (X) e Desvio Padrão (DP) dos valores de RMS normalizados pela CIVM a 50 de flexão do joelho dos músculos vasto medial

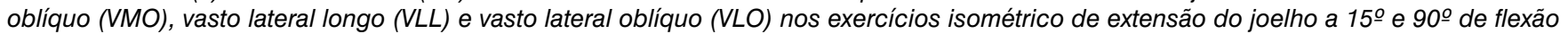
$(n=21)$. Valores significativos para $p \leq 0.05$.

Table 1 - Median $(X)$ and standard deviation (DP) of the RMS values normalized by CIVM at 50 of knee flexion of the vastus medialis obliquus muscle (VMO), vastus lateralis longus (VLL) and vastus lateralis obliquuus (VLO) during isometric exercises the knee extension at 150and $900^{\circ}$ of flexion $(n=21)$ significant difference at $p \leq 0.05$.

\section{DISCUSSÃO}

Um dos propósitos deste estudo foi verificar se os músculos VLL e VLO apresentavam diferenças funcionais, e os resultados revelaram que estes músculos possuem um padrão diferente de recrutamento, isto é, além das diferenças anatômicas ${ }^{(1)}$ apresentam padrão de ativação distintos.

Nos exercícios de extensão isométrica de joelho a $15^{\circ}$ de flexão, estes músculos não apresentaram entre si diferença significativa, e diferentemente do VLO que manteve o mesmo padrão de recrutamento independente do ângulo de flexão do joelho, o VLL é significativamente mais ativo na extensão do joelho a $15^{\circ}$ do que a $90^{\circ}$. Embora a diferença não tenha sido significante, Boucher et al. ${ }^{(3)}$, também encontraram maior atividade do VLL a $15^{\circ}$ do que a $90^{\circ}$. Da mesma forma, Escamilla et al. ${ }^{(6)}$ também relataram maior atividade do músculo VLL nos últimos graus de extensão.

Cerny ${ }^{(4)}$, atribuiu esta maior atividade do VLL a $15^{\circ}$ à desvantagem mecânica em decorrência do aumento da gravidade e do braço de alavanca do músculo quadríceps, além da diminuição do comprimento muscular.

Para Boucher et al. ${ }^{(3)}$, o músculo VLL quando em atividade na CIVM à $15^{\circ}$ de flexão, está mais envolvido com a extensão do joelho do que a estabilização da patela. Isto se justifica também pelo alinhamento das fibras do VLL, cuja tendência é tracionar a patela superiormente promovendo a extensão, diferentemente do VLO, que com suas fibras em espiral e inclinadas em relação à diáfise femoral $^{(1)}$ se responsabiliza pelo alinhamento da patela juntamente com o VMO. Além disso, o músculo VLL apresenta maior massa muscu$\operatorname{lar}^{(24)} \mathrm{com}$ um componente de tracionamento maior do que o VLO, estando, portanto, mais propenso às alterações no seu comprimento. Por outro lado, na CIVM $15^{\circ}$, ambos estão numa posição de encurtamento onde apesar das diferenças anatômicas, a constituição e a disposição das fibras parecem não promover grandes alterações na relação comprimento tensão.

Os resultados deste trabalho sugerem que ao realizarmos os exercícios nos últimos graus de extensão, além de não ativarmos preferencialmente o VMO, favorecemos a ação do VLL, podendo contribuir para o desequilíbrio patelar.

Em relação à atividade elétrica do músculo VLO, o único trabalho encontrado na literatura pesquisada até a presente data, que faz referência direta ao estudo eletromiográfico do VLO é o de Morrish e Wo

\section{DISCUSSION}

One of the purposes of this study was to verify if the VLL and VLO showed differences in their function, and the results revealed different recruiting pattern in these muscles, besides the anatomical differences ${ }^{(1)}$ they also showed distinct activation pattern.

During the isometric extension exercises of knee at $15^{\circ}$ flexion, these muscles did not show any remarkable difference among them, differently from VLO, which remained with the same recruitment pattern independent of the knee flexion angle, the VLL is significantly more active during the knee flexion at $15^{\circ}$ than at $90^{\circ}$. Although the difference was not so significant, Boucher et al..$^{(3)}$, also observed more VLL activity at $15^{\circ}$ than $90^{\circ}$. Either, Escamilla et al. ${ }^{(6)}$ also reported more activity of the VLL muscle at last knee extension degree.

Cerny ${ }^{(4)}$, associated this higher VLL activity at $15^{\circ}$ as a mechanical disadvantage due to the increase of the gravity and the lever of the quadriceps muscle, besides the decrease of the muscle length.

According to Bouncher et al.(3), the VLL muscle while working in MICV at $15^{\circ}$ flexion, is more involved in the knee extension than the patella stability. This also shows the VLL fibers alignment that tends to tractionate patella promoting the extension, differently from the VLO which spirally and inclination fibers in relation to femoral dyaphisis promotes ${ }^{(1)}$ the patella alignment associated to the VMO. In addition, the VLL muscle shows a greater muscular body(24) with a higher traction component than the VLO, therefore, more available to alterations in its length. On the other hand at (MIVC) $15^{\circ}$, both are in the shortening position spite of the anatomical differences, the fibers structure and disposition seem not promoting important alterations in relation of the length tension.

The comes out of this work suggest when doing the exercise at the last extension degrees, besides not activate preferably the VMO, the action of the VLL is preferred, contributing to the pate/lar balancing.

About the VLO muscle electrical activity, the only work referring to the VLO electromyographical study, is the one by Morrish \& Woledge ${ }^{(16)}$, who also studied the VMO at $20^{\circ}$ degree knee flexion in an opening kinetic chain and no important differences 
ledge ${ }^{(16)}$, que também analisaram o músculo VMO no ângulo de $20^{\circ}$ de flexão do joelho em cadeia cinética aberta e, não encontraram diferenças significativas na atividade destes músculos que foi praticamente sincrônica, sugerindo uma atividade recíproca no controle patelar.

De acordo com Javadpour et al. ${ }^{(11)}$ o equilíbrio entre a tração do VMO e VLO é primordial já que é o fator muscular que determina a posição da patela, uma vez que o exercício em cadeia cinética aberta de extensão da perna isola a contração do quadríceps. Os dados deste estudo revelaram que os músculos VMO e VLO apresentam o mesmo comportamento sugerindo um papel estabilizador sincrônico e com uma função antagonista na estabilização patelar em indivíduos normais.

Por outro lado o vetor de força exercido pelo músculo VLO, intimamente associado ao tracto íliotibial e retináculo lateral ${ }^{(1)}$ pode ser capaz de alterar o equilíbrio normal da patela, gerando tensão excessiva nessas estruturas podendo desencadear um quadro de dor e mau alinhamento patelar.

O conceito de que o músculo VMO é mais ativo durante os últimos graus de extensão é amplamente aceito(6,13,17), o que subsidiou o uso destes exercícios no tratamento conservador. Da mesma forma, o conceito de que a força de reação femoropatelar aumenta com a flexão do joelho e diminui na medida que alcançava-se a extensão final proposto por Hungerford e Barry ${ }^{(10)}$, contribuiu para que o protocolo de exercícios para estes pacientes fosse baseado em exercícios realizados nos últimos graus de extensão.

Os dados deste trabalho revelaram que o músculo VMO não é mais ativo nos últimos graus, o que concorda com Boucher et al. ${ }^{(3)}$, Doucete e Child(5), Herrington e Payton ${ }^{(9)}$, que também não encontraram diferenças na atividade do músculo VMO nos em diferentes ângulos de flexão do joelho em indivíduos normais.

Apesar do aumento da atividade na CIVM a $90^{\circ}$ dos músculos VMO e VLO não ser significativa em relação ao ângulo de $15^{\circ}$, os resultados demonstraram que a diferença entre estes dois músculos e o músculo VLL aumenta na medida em que aumenta o ângulo de flexão do joelho.

Além disso, segundo Boucher et al. ${ }^{(3)}$, na angulação de $90^{\circ}$, as forças compressivas são maximizadas e a força de cisalhamento são minimizadas facilitando não somente a atividade do músculo VMO mas aumentando o contato articular e favorecendo a nutrição articular.

Para o fortalecimento seletivo do músculo VMO, o que se procura não é somente o arco de movimento onde o mesmo apresente maior atividade, mas que também possa oferecer maior estabilidade, meIhor distribuição de forças compressivas e também maior ativação em relação aos componentes laterais.

Os exercícios de fortalecimento do músculo VMO nos últimos graus de extensão até hoje tem sido preconizados para o tratamento destes pacientes. No entanto, é fundamental que além de mais ativo, o músculo VMO apresente uma vantagem de ativação em relação ao VLL e VLO.

Nos últimos graus de extensão do joelho há ainda menor contato articular, portanto maior instabilidade e Steikamp et al. ${ }^{(19)}$, demonstraram que nos últimos graus dos exercícios de extensão em cadeia cinética aberta, há também maior estresse femoropatelar já que o contato articular nesta angulação é menor, portanto as forças compressivas apesar de menores são distribuídas numa menor área de contato, aumentando o estresse. Por outro lado, o ângulo de $90^{\circ}$ de flexão do joelho, apresenta uma força de reação femoropatelar maior, mas maior também é o contato articular e a estabilidade femoropatelar. Sendo assim, os autores demonstraram que o estresse femoropatelar diminui à medida que aumenta o ângulo de flexão do joelho. in these muscles activity, nearly synchronic were found, suggesting a reciprocal activity at the patella control.

According to Javadpour et al. ${ }^{(11)}$ the traction balancing of the VMO and VLO is fundamental considering its muscular factor which determines patella position, as the opening kinetic chain exercise of the leg extension isolating the quadriceps contraction. The data from this study showed that VMO and VLO muscles have the same behaviour suggesting a synchronic role of stability and an antagonist stability of the patella in normal people.

On the other hand the strength vector made by the VLO muscle, very associated with the iliotibial tract and lateralis retinaculum ${ }^{(1)}$ may be able to alter the patella normal balancing, promoting an excessive tension in these structures could generate clinical pain and patella disorder.

Considering the VMO muscle being more active during the last extension degrees it is well known ${ }^{(6,13,17)}$, what subsided the use of these exercises in this traditional treatment. Equally, the concept of the strength of patellofemoral reaction increases according to knee flexion and decrease as long as reaching the final extension proposed by Hungerford \& Barry ${ }^{(10)}$, contributed to the exercises protocol to these patients that were based on exercises done at the last extension degrees.

This work data showed the VMO muscle is not the most active at the last degrees., which is in accordance to Boucher et al. ${ }^{(3)}$, Doucete \& Child(5), Herrington \& Payton ${ }^{(9)}$, who did not find difference in VMO muscle activity at different angles of knee flexion in normal patients.

Spite of the increase of the activity in CIVM at $90^{\circ} \mathrm{VMO}$ and VLO muscles not be significant in relation to $15^{\circ}$ of knee flexion, the results showed the difference between these two muscles and the VLL muscle increasing as much as the knee flexion angle increases.

Furthermore, according to Boucher et al. ${ }^{(3)}$, at $90^{\circ}$, the compressive strength is maximized and the shearing strength is minimized facilitating not only VMO muscle activity, but also increasing the articular contact facilitating articular nutrition.

For the VMO selective muscle training, it is not only the Arch of movement what is searched where it shows more activity, but also offer higher stability, better compressive strength higher activation in relation to the lateralis components.

The strength exercise of the VMO muscle at the last degrees extension until now has been proclaimed to these patients treatment. However, it is essential to this muscle, besides being more active, the VMO muscle show an advantage of activation if compared to VLL and VLO.

At the last knee extension degrees there is even less articular contact, therefore higher and instability Stickup et al. ${ }^{(19)}$, showed that at the last degrees of the extension exercises done in opening kinetic chain, there is also higher patellofemoral stress, as the particular contact angle is smaller, nevertheless the compressive strength, despite being smaller is distributed in a small contact area, increasing the stress. Otherwise, the $90^{\circ} \mathrm{knee}$ flexion, shows a higher strength of the stress, but the articular contact and the patellofemoral is higher as well., consequently the authors showed the patellofemoral decreases due to the increase of the knee flexion angle.

Therefore, the isometric contraction exercise of the knee extension flexion at $90^{\circ}$ can be proscribed to the rehabilitation program which is indicate VMO strength exercise. 
Portanto, os exercícios de contração isométrica de extensão de joelho a $90^{\circ}$ de flexão podem ser indicados para o programa de reabilitação em que há indicação do fortalecimento do VMO.

\section{CONCLUSÕES}

Os Músculos VLL e VLO apresentaram diferença no padrão de atividade podendo ser considerados fisiologicamente distintos. Além disso, o músculo VLO apresentou-se assim como o VMO igualmente ativo, independente do ângulo de flexão do joelho, sugerindo que estes músculos desempenham papel recíproco e sincrônico na estabilização patelar. Os exercícios isométricos de extensão do joelho a $90^{\circ}$ revelaram que ocorre maior ativação do músculo VMO em relação aos componentes laterais, com diferença significativa em relação ao músculo VLL.

\section{CONCLUSION}

The VLL and VLO muscles showed difference in the activity pattern, which could be considered physiologically distinct. Besides, the VLO muscle as the VMO also active, independent of the knee flexion angle, suggesting these muscles performance in reciprocal and synchronic patella stability. The isometric exercises of the knee extension at $90^{\circ}$ higher activation of the VMO muscle was obsereved during in relation to lateral-components, with important difference in relation to VLL muscle.

\section{REFERÊNCIAS BIBLIOGRÁFICAS}

1. Bevilaqua-Grossi D, Monteiro-Pedro V, Sousa GC, Silva Z, Bérzin F. Contribution to the anatomical study of the oblique portion of the Vastus Lateralis Muscle. Braz. J. Morphol. Sci, v.21, 47-52, 2004.

2.Bose $\mathrm{K}$, Kanagasuntheram R, Osman MBH. Vastus medialis oblique: an anatomical and physiologic study. Orthopedics., v. 3, pp. 880-883, 1980.

3.Boucher JP, King MA, Lefebure R, Pepin A. Quadriceps femoris muscle activity in patellofemoral pain syndrome. Am J Sports Med 20:527-532, 1992.

4.Cerny K. Vastus medialis oblique/vastus lateralis muscle activity ratios for selected exercises in persons with and without patellofemoral pain syndrome. Phys Ther 75:672-683, 1995

5. Douchete SA, Child DD. The effect of open and closed chain exercise and knee joint position on patellar tracking in lateral patellar compression syndrome. J Orthop Sport Phys Ther 20:104-110, 1996.

6. Escamilla RF, Fleising GS, Zheng N, Barrentine SW, Wilk KE, Andrews JA. Biomechanics of the knee during closed kinetic chain and open kinetic chain exercises. Med Sci Sports Exerc 30:556-569, 1998.

7. Hallisey M, Doherty N, Bennett WF, Fulkerson JP. Anatomy of the junction oh the vastus lateralis tendon and patella. J Bone Joint Surg Am 69:545-549, 1987.

8. Hanten WP, Schulthies SS. Exercise effects on electromyographic activity of the vastus medialis oblique anda vastus lateralis muscles. Phys Ther 13:561-565, 1990

9. Herrington L, Payton CJ. Effects of corrective taping of the patella on patients with patellofemoral pain. Physiother 83:566-572, 1997.

10. Hungerford DS, Barry M. Biomechanics of the patellofemoral joint. Clin Orthop $144: 9-15,1979$

11.Javadpour SM, Finegan PJ, O'Brien M. The anatomy of the extensor mechanism and its clinical relevance. Clin J Sport Med 1:229-235, 1991

12.Lieb FJ, Perry J. Quadriceps function: an anatomic and mechanical study using amputaded limbs. J Bone Joint Surg Am 50:1535-1548, 1968.

13.Lieb FJ, Perry J. Quadriceps function: an electromyografic study under isometric conditions. J Bone Joint Surg Am 53:749-758, 1971.
14.Monteiro-Pedro V, Novaes PD, Silva E. FOP-UNICAMP. [Comunicação Pessoal], 1992.

15.Monteiro-Pedro V, Vitti PM, Berzin F, Bevilaqua-Grosso D. Electromyographic (EMG) Study of the vastus medialis oblique $(\mathrm{VMO})$ and vastus lateralis $(\mathrm{VL})$ muscles in the hip adduction and knee extension exercices. Braz $\mathrm{J}$ Morphol Sci 14:167, 1997.

16. Morrish GM, Woledge RC. A comparison of the activation of muscles moving the patella in normal subjects and in patients with chronic patellofemoral problems. Scand J Rehab Med 29:43-48, 1997.

17.Ruffin MT, Kinigham RB. Anterior knee pain: the challenge of patellofemoral syndrome. Am Fam Physician 43:185-194, 1993

18.Scharf W, Weinstabl R, Orthner E. Anatomical separation and clinical importance of two different parts of the vastus medialis muscle. Acta Anat (Basel) 123:108-111, 1985.

19. Steinkamp LA, Dillingham MF, Markel MD, Hill JA, Kaufman KR. Biomechanical considerations in patellofemoral joint rehabilitation. Am J Sports Med 21:438-444, 1993.

20.Thiranagama R. Nerve supply of human vastus medialis muscle. J Anat 70:193198, 1990.

21. Travnik L, Pernus F, Erzen I. Histochemical and morphometric characteristics of the normal human vastus medialis longus and vastus medialis obliquus muscles. J Anat 187: 403-411, 1995.

22.Vaatainen U, Airaksinen, Jaroma H., Kiviranta I. Decreased torque and electromyographic activity in the extensor thigh muscles in chondromalacia patellae. Int J Sports Med 16:45-50, 1995.

23.Weinstabl R, Scharf W, Firbas W. The extensor apparatus of the knee joint and its peripheral vasti: anatomic investigation and clinical relevance. Surg Radio Anat 11:17-22, 1989

24.Wickiewicz TL, Roy RR, Powel PL, Edgerton VR. Muscle archuiteture of the human lower limb. Clin Orthop 179:275-283, 1983

25. Wilk KE, Reinold MM. Principles of Patellofemoral Rehabilitation. Sports Medicine and Arthroscopy Review, v.9, pp. 325-336, 2001. 